\title{
An experimental study on the role of crustacean and microprotozoan grazers in the planktonic food web
}

\author{
Kai Kivi*, Harri Kuosa**, Sanna Tanskanen ${ }^{* * *}$ \\ Tvärminne Zoological Station, University of Helsinki, FIN-10900 Hanko, Finland
}

\begin{abstract}
The roles of inorganic nutrients and grazing by crustaceans and microprotozoans as factors shaping the planktonic community of the Gulf of Finland were studied in a $6 \mathrm{~d}$ laboratory experiment. The removal of metazoans $>100 \mu \mathrm{m}$ greatly enhanced microprotozoan growth during the last $3 \mathrm{~d}$ of the experiment. When inorganic $N$ and $P$ additions were combined with the removal of metazoans, the growth of protozoans was stimulated even further. On the other hand, addition of metazoans $>200 \mu \mathrm{m}$ kept the protozoan populations low, even in the presence of extra $\mathrm{N}$ and $\mathrm{P}$. In connection with high protozoan numbers, the growth of phytoplankton $>10 \mu \mathrm{m}$ was enhanced, while the 1-10 $\mu \mathrm{m}$ phytoplankton populations decreased towards the end of the experiment. With abundant metazooplankton and nutrient additions (and only few protozoans), phytoplankton in the size range of 1 to $10 \mu \mathrm{m}$ flourshed, while $>10 \mu \mathrm{m}$ phytoplankton bromass did not rise above the initıal level. Whether the grazer community was dominated by protozoans or metazoans did not have much effect on picoalgal $(<2 \mu \mathrm{m})$ growth, but the presence of crustaceans resulted in increased bacterial production in nonnutrient-enriched conditions. The results suggest that total phytoplankton biomass is largely determined by both nutrient availability and grazer activities, and can be quite similar in both proto- and metazoan-dominated communities. However, the structure of the prey communities $>2 \mu \mathrm{m}$ depends on the composition of the grazer populations. The biomass and composition of microprotozoan communities also appear largely to depend on the shaping effect of metazoan grazers. Nutrient recycling by crustaceans seems to enhance bacterial production, and possibly also picoalgal growth.
\end{abstract}

KEY WORDS: Crustaceans Microprotozoans - Nutrients Grazing Food web shaping

\section{INTRODUCTION}

The regulation of phytoplankton biomass, production, and community structure has often been considered to be the consequence of resource limitation (mainly inorganic nutrients) and the different abilities of different algal species to compete for these resources. In searching for the limiting nutrient, or optimum nutrient ratios for different species (e.g Rhee \& Gotham 1980), the rest of the planktonic community

Present addresses:

- Finnish Environment Agency, PO Box 140, FIN-00251. Helsinki,Finland.E-mall:kai.kivi@vyh.fi

- Finnish Institute of Marine Research, PO Box 33, FIN-00931, Helsinkı, Finland

-.. University of Helsinki, Department of Ecology and Systematics, Division of Hydrobiology, PO Box 17. Arkadiankatu 7, FIN-00014, Helsinki, Finland has thus been paid less attention, although attempts to study the role of zooplankton in transitions of growth limitation by different nutrients have been made (Elser et al. 1988). However, it is obvious that regulatory mechanisms other than resource limitation must also play a role in the development of phytoplankton communities. A contrasting case would be a situation where phytoplankton communities have all the possible resources needed, but are controlled, and their structure determined, by grazing heterotrophic organisms (McQueen et al. 1986). In the light of today's knowledge, both mechanisms appear to function in planktonic ecosystems during most of the annual productive period (Thingstad \& Sakshaug 1990, Kivi et al. 1993), although the dominant mechanism can be strongly afferter hy nhysical forring (for example. algal blooms following an upwelling, etc.). If we take a look at the ecosystem through a wide-angle lens, we can observe analogous phenomena taking place on 
different trophic levels. For example, nanoflagellates are the limiting resource for micraciliate growth (Rassoulzadegan et al. 1988), whereas ciliate production and community structure are under strict control of copepods (Nielssen \& Kiorboe 1994), whose production in turn seems to be regulated both by availability of phytoplankton suitable as food and also by ciliates, which as the go-betweens transform flagellate carbon to an edible form for copepods. This leads to the modern concept of planktonic food webs, where the socalled grazing chain (sensu Steele 1974) and the microbial loop intertwine, so that both limiting and controlling mechanisms are at work simultaneously (e.g. Sherr \& Sherr 1988).

The aim of this study was 2 -fold: first, in experimental ecosystems we studied the effect of inorganic nutrient enrichment on the phytoplankton community in the absence of metazoans with initially few microprotozans present. Second, we tried to assess the effect of adding large numbers of metazoan grazers to nutrientenriched and non-enriched tanks, and to trace the outcome of this manipulation under different nutritional conditions. This framework also enabled us to examine differences at lower trophic leveis in planktonic communities, regulated by either crustacean or microprotozoan grazing In addition to these main objectives, we also tried to estimate microprotozoan and copepod grazing impact on the phytoplankton populations. In this paper, we attempt to give a general picture on how the planktonic communities in the 4 different tanks developed during $6 \mathrm{~d}$, and also present the effects of the treatments on the function of the experimental ecosystems.

\section{MATERIALS AND METHODS}

The experiment was conducted in 4 transparent acrylic tanks at a steady $18^{\circ} \mathrm{C}$ and $18 \mathrm{~h}$ light $/ 6 \mathrm{~h}$ dark circadian light cycle. The illumination was adjusted to correspond to the light levels at approximately $5 \mathrm{~m}$ depth $\left(100 \mu \mathrm{E} \mathrm{cm}{ }^{-2} \mathrm{~s}^{-1}\right)$. First, $100 \mathrm{l}$ of surface seawater was poured into each tank through a $100 \mu \mathrm{m}$ plankton net to remove metazoan plankton. The manipulations used were phosphate $\left(\mathrm{PO}_{4}{ }^{3-}-\mathrm{P}\right)$ and ammonium $\left(\mathrm{NH}_{4}{ }^{+}-\mathrm{N}\right)$ additions of 20 and $100 \mu \mathrm{g} \mathrm{l}^{-1}$, respectively, and the addition of ca 100 -fold concentration (compared to that of natural) of $>200 \mu \mathrm{m}$ metazooplankton (experimental design in Table 1). The water for the experiments was collected in the evening of 7 September 1993 off Tvärminne Långskär ( $\left.59^{\circ} 49^{\circ} \mathrm{N}, 23^{\circ} 17^{\prime} \mathrm{E}\right)$, on the SW coast of Finland. Nutrient and zooplankton additions, as well as the first sampling, took place the next morning at 9:00 h, which was also the time for the subsequent samplings. A second nutrient addition (similar to the first) was performed on Day 3 of the experiment; zooplankton was added only on Day 1 The water in the tanks was thoroughly mixed after additions and prior to samplings.

Chlorophyll a (chl a) was measured from 3 different size-fractions $(<1 \mu \mathrm{m},<10 \mu \mathrm{m}$, and total, i.e. unfractionated). Nuclepore polycarbonate filters were used for the fractionation. Two replicate samples of $250 \mathrm{ml}$ from each fraction were filtered with Whatman GF/F glassfiber filters. The samples were ultrasonicated for $10 \mathrm{~min}$, and then extracted in $20 \mathrm{ml}$ plastic scintillation vials with $10 \mathrm{ml}$ of $94 \%$ ethanol at room temperature and darkness for $24 \mathrm{~h}$. The concentration of chl a was measured with a Shimadzu UV-2101 PC spectrophotometer

For primary production measurements, the samples were fractionated $(<1 \mu \mathrm{m},<10 \mu \mathrm{m}$, and total) through Nuclepore filters prior to the incubations. Three light replicates and 1 dark sample were incubated for $3 \mathrm{~h}$ under the same conditions as the tanks. The incubations were started by adding $1 \mu \mathrm{Ci}$ of $\mathrm{NaH}^{14} \mathrm{CO}_{3}\left({ }^{14} \mathrm{C}\right.$ Centralen, Denmark) in the $20 \mathrm{ml}$ incubation vials, and they were terminated by $100 \mu \mathrm{l}$ additions of $38 \%$ formaldehyde. From here on, the procedure followed the method of Niemi et al. (1983). HiSafe 3 (Wallac, UK) was used as the scintillation cocktail, and the radioactivity was measured with a Rackbeta 1215 liquid scintillation counter (Wallac, Finland) by the external-standard channel ratio method. Dark values were subtracted from the corresponding averages of the 3 light replicates. Dissolved inorganic $\mathrm{C}$ was measured with an Elektro-Dynamo carbon analyzer (Laitila, Finland).

Bacterial production was assessed by using the tritiated thymidine incorporation method (Fuhrman \& Azam 1982). Triplicate $20 \mathrm{ml}$ samples were incubated for $1 \mathrm{~h}$ under the previously mentioned constant conditions with $10 \mathrm{nM}$ of [methyl- ${ }^{3} \mathrm{H}$ ] thymidine (specific activity $1.0 \mathrm{mCi} \mathrm{ml}^{-1}$, Amersham, UK). One pre-killed blank was used for every 3 replicates. In a preliminary experiment, the saturating concentration for thymidine incorporation rate was found to be $5 \mathrm{nM}$ or less. Trichloroacetic acid (TCA) extraction, radioactivity

Table 1 The $2^{2}$ experimental design. The water in all tanks was pre-filtered through a $100 \mu \mathrm{m}$ sieve. +: manipulation performed $_{i}-$ : no manipulation. The manipulations: NP: nutrient addition; $\mathrm{Z}$ : addition of $>200 \mu \mathrm{m}$ zooplankton

\begin{tabular}{ccc|}
\hline Tank & NP & Z \\
\hline 1 & - & - \\
2 & + & - \\
3 & - & + \\
4 & + & + \\
\hline
\end{tabular}


measurements and production calculations were performed as in Kivi et al. (1993).

Picoplanktonic algae were enumerated by epifluorescence microscopy according to Haas (1982). Their carbon content was estimated by using a conversion factor of 0.22 of cell biovolume (Børsheim \& Bratbak 1987). Enumeration of microprotozoa and metazooplankton, and the qualitative examinations of phytoplankton were done with Leitz inverted microscopes according to the Utermöhl (1958) method. Phytoplankton and microprotozoa were preserved with acid Lugol's solution; metazoans were fixed with formaldehyde ( $4 \%$ final concentration).

The organic $\mathrm{C}$ content of microprotozoa was estimated by using previously measured biovolumes (Kivi unpubl.), and a conversion factor of 0.11 (Edler 1979). For metazoans, we used the standard biovolume values of the Finnish Institute of Marine Research. These biovolumes were converted to organic $C$ values using a factor of 0.06 (Mullin 1969). In order to assess correspondence between estimated and measured $C$ contents, we made direct measurements of Acartia bifilosa and Bosmina coregoni maritima according to the method of Latja \& Salonen (1978) using the ElektroDynamo carbon analyzer.

Ciliate grazing was studied by using wheat starch particles as a tracer food source (Kivi \& Setälä 1995). In the experiments, samples from Tanks 1 and 2 were put into 21 polycarbonate bottles. Starch particles $<40 \mu \mathrm{m}$ were added into the bottles to reach a concentration of $10^{6} \mathrm{l}^{-1}$. The samples were incubated for $10 \mathrm{~min}$ in a $18^{\circ} \mathrm{C}$ water bath, after which a $500 \mathrm{ml}$ subsample was fixed with acid Lugol's solution. Clearance rates for different food particle sizes were computed from the ingestion rates obtained by counting and sizing the particles inside the ciliate cells. These rates were, in turn, used in estimating the impact of ciliate populations on their prey items.

Grazing experiments with metazooplankton were limited to adult females of Acartia bifilosa. The biomass of the species corresponded to ca $30 \%$ of the biomass of the added metazoans. Their grazing was studied by using an application of the gut chlorophyll a content method (Mackas \& Bohrer 1976, Kiørboe et al. 1982) with 4 algal species (Synechococcus sp., Nannochloropsis sp., Pavlova lutheri, and Brachiomonas sp.) of different sizes from cultures used as food. Thirty individual copepods were placed in 1 l Erlenmeyer flasks with $500 \mathrm{ml}$ of filtered seawater (Whatman $\mathrm{GF} / \mathrm{F})$. Algae from the cultures were added to reach a chl a concentration of 5 to $10 \mu \mathrm{g} \mathrm{l}$ '. The flasks were iñcubated at $18^{\circ} \mathrm{C}$ for 3 h whilc attachod to an automatic shaker $(50 \mathrm{rpm})$. After this, the water from each experimental unit was poured through a $100 \mu \mathrm{m}$ filter, and the animals recovered on the filter were counted.
The $100 \mu \mathrm{m}$ filters, with the copepods on them, were put into plastic $20 \mathrm{ml}$ scintillation vials, and $10 \mathrm{ml}$ of $94 \%$ ethanol was added. The vials were ultrasonicated for $10 \mathrm{~min}$ in order to break down the animals and the algal cells in their guts. The samples were left to extract overnight in the dark (at room temperature). and the chl a measurements were taken the next day with a Shimadzu RF-5000 spectrofluorometer.

\section{RESULTS}

\section{Bacterial production}

The results of the bacterial production measurements are presented in Fig. 1A. In Tank 1, the thymidine uptake of the bacteria remained at the initial level during the whole experiment, whereas in Tank 3, it was somewhat elevated in the middle of the experiment, but returned back to the starting value at the end of the experiment. In Tanks 2 and 4 (with the nutrient additions) bacterial production had already increased almost $150 \%$ on Day 3 of the experiment, and remained at this high level until the end.
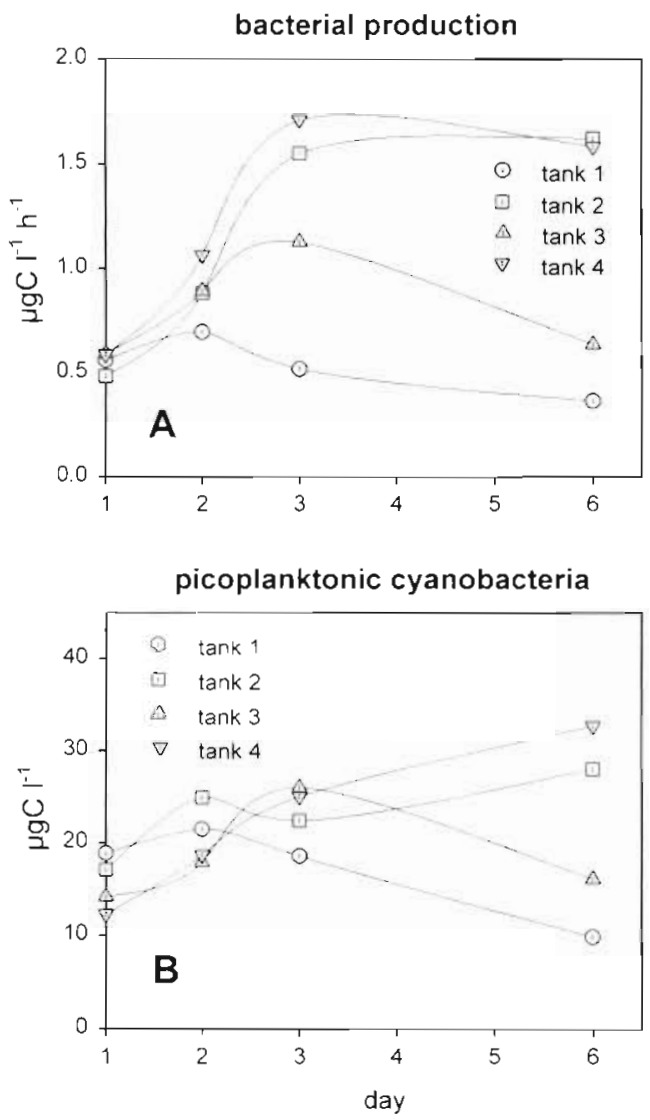

Fig. 1 Bacterial production (A) and development of picocyanobacteria biomass (B) during the experiment 

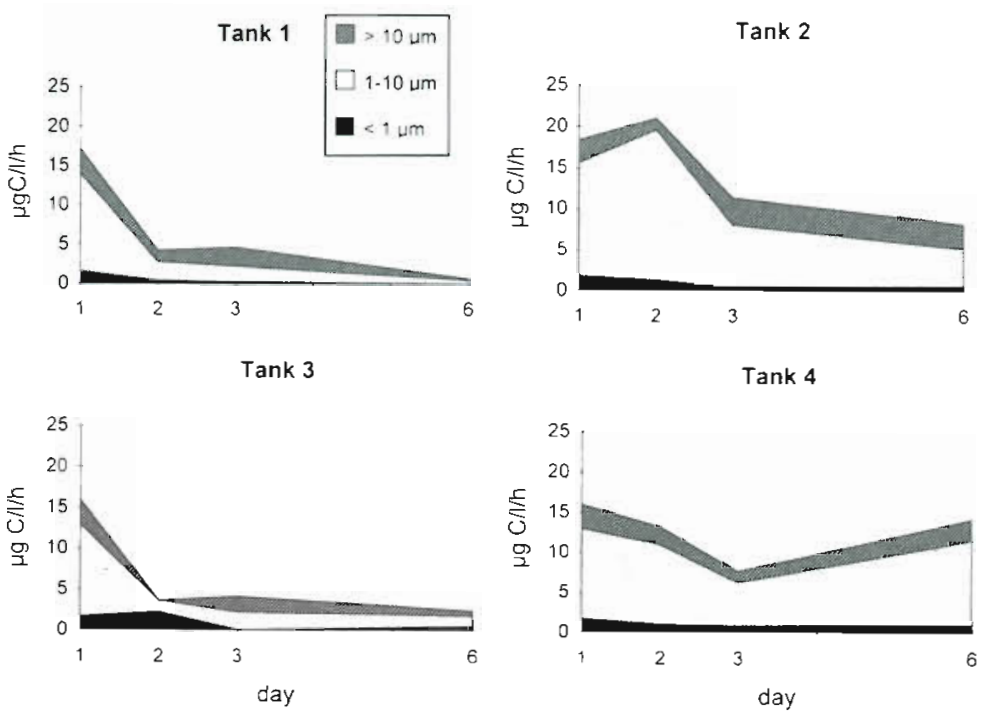

Fig. 2. Development of phytoplankton primary production $<1,1-10 \mu m$, and $>10 \mu \mathrm{m}$ in the 4 tanks during the experiment

\section{Picoplanktonic cyanobacteria}

The development of picoplanktonic cyanobacteria biomass resembled that of bacterial production (Fig. 1B). The main differences started to show on Day 3 of the experiment, when the cell numbers in Tank 1 started lagging behind the others. On the final day, the pattern was similar to that of the bacteria: the cell numbers in Tanks 2 and 4 had increased at least 2 -fold from the initial numbers, whereas in the 2 other tanks, with no nutrient additions, the numbers had declined (in Tank 1 even below the starting level). in Tank 4 followed its own pattern: there were no large changes from the initial situation, with the exception of the increase in production in the $1-10 \mu \mathrm{m}$ fraction towards the end of the experiment.

Total chl a level was initially at a medium level (ca $7 \mu \mathrm{g} \mathrm{l}^{-1}$ ). In Tanks 1 and 3 no remarkable changes took place in the 3 fractions during the experiment, with the exception of the $<1 \mu \mathrm{m}$ fraction, the relative proportion of which was higher in Tank 3 than in Tank 1 from Day 2 on (Fig. 3). In Tank 2, there was a 3 -fold increase during the first day, especially in the $1-10 \mu \mathrm{m}$ fraction. After this, the total chl a remained on a high level, but this was mainly due to the increase in the largest fraction, which compensated for the losses in the $1-10 \mu \mathrm{m}$ fraction. In Tank 4, the total chl a slowly increased towards the end of the experiment, but here the cause was the growth of phytoplankton in the 1-10 $\mu \mathrm{m}$ fraction. No large changes in the smallest $(<1 \mu \mathrm{m})$ fraction were observed in any of the tanks during the experiment.

The phytoplankton communities in the tanks consisted mainly of flagellates in the $1-10 \mu \mathrm{m}$ size class (Pyramimonas sp., Cryptomonas sp. and a multitude of unidentified prymnesiophytes). In the $>10 \mu \mathrm{m}$ size class, the most numerous phytoplankters were Eutreptiella gymnastica, some dinoflagellates (Katodinium sp., and the relatively large Dinophysis acuminata), and some centric diatoms, like the large Coscinodiscus granii.
Primary production, chl $a$, and phytoplankton

In the beginning of the experiment, primary production levels in all tanks were rather high

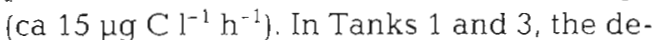
velopment followed similar courses during the whole experiment (Fig. 2). In these tanks, there were no notable differences among the 3 phytoplankton size-fractions: from the high initial level, the primary production rapidly declined during the first $24 \mathrm{~h}$ down to less than $5 \mu \mathrm{g} \mathrm{Cl}^{-1} \mathrm{~h}^{-1}$, and remained low during the rest of the experiment. In Tanks 2 and 4 the succession was quite different. In Tank 2 . the production in the 1-10 $\mu \mathrm{m}$ fraction increased rapidly during the first $24 \mathrm{~h}$, and then fell to around $5 \mu \mathrm{gCl}^{-1} \mathrm{~h}^{-1}$ During the whole experiment, the production in the $>10 \mu \mathrm{m}$ fraction slowly increased. Primary production
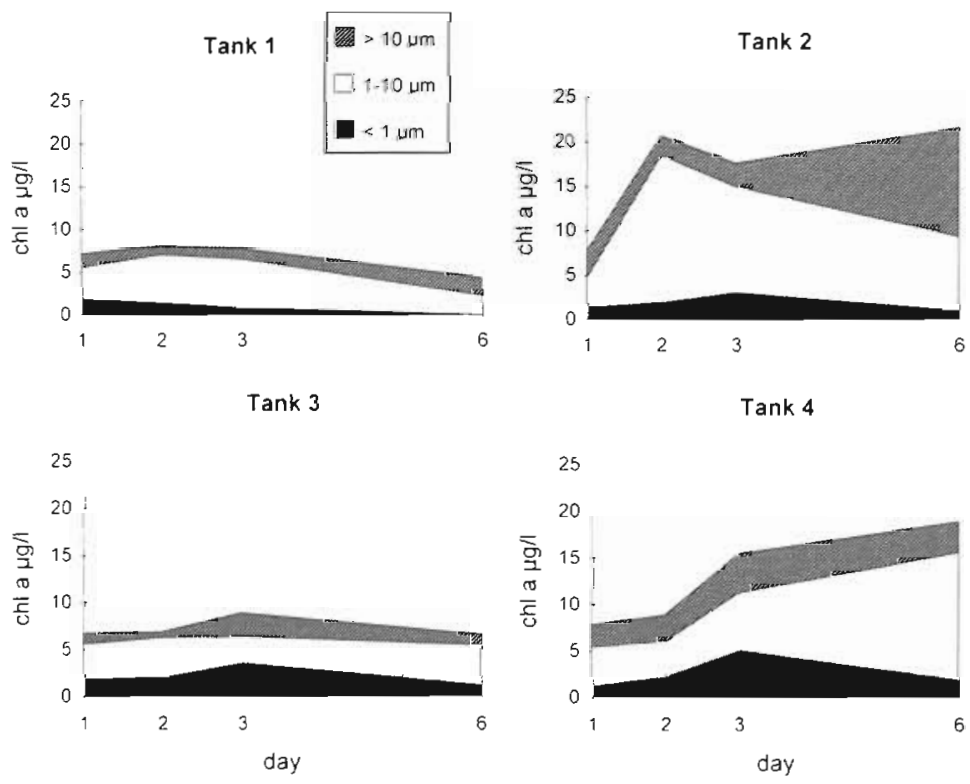

Fig. 3. Development of chl a in the 4 tanks during the experiment 


\section{Microprotozoa}

During the first $3 \mathrm{~d}$ of the experiment, microprotozoan (ciliates and heterotrophic microflagellates) biomass was low (ca $50 \mu \mathrm{g}$ wet $\mathrm{wt}^{-1}$, corresponding to about $5 \mu \mathrm{g} \mathrm{C}^{-1}$ ). The community consisted mainly of tintinnids (Tintinnopsis lobiancoi, T. brandti, and Leprotintinnus bottnicus) and heterotrophic microflagellates (the overwhelming majority of which were of the ca $30 \mu \mathrm{m}$ ebridian species Ebria tripartita). The situation changed rapidly during the next $3 d$ (Fig. 4). In Tanks 1 and 2, where no metazooplankton was added, the microprotozoan growth accelerated tremendously. This huge growth was accompanied by a total shift in the community structure. In Tank 2, where the growth was most pronounced, we calculated total population growth rates of $\mu=1.29 \mathrm{~d}^{-1}$, which corresponds to a 48 -fold increase during the last $3 \mathrm{~d}$. The growth in Tank 1 was approximately half of this. In these 2 tanks the tintinnid-dominated community transformed into a domain of aloricate ciliates, where oligotrichs of the genera Lohmanniella, Strobilidium, and Strombidium had a major role.
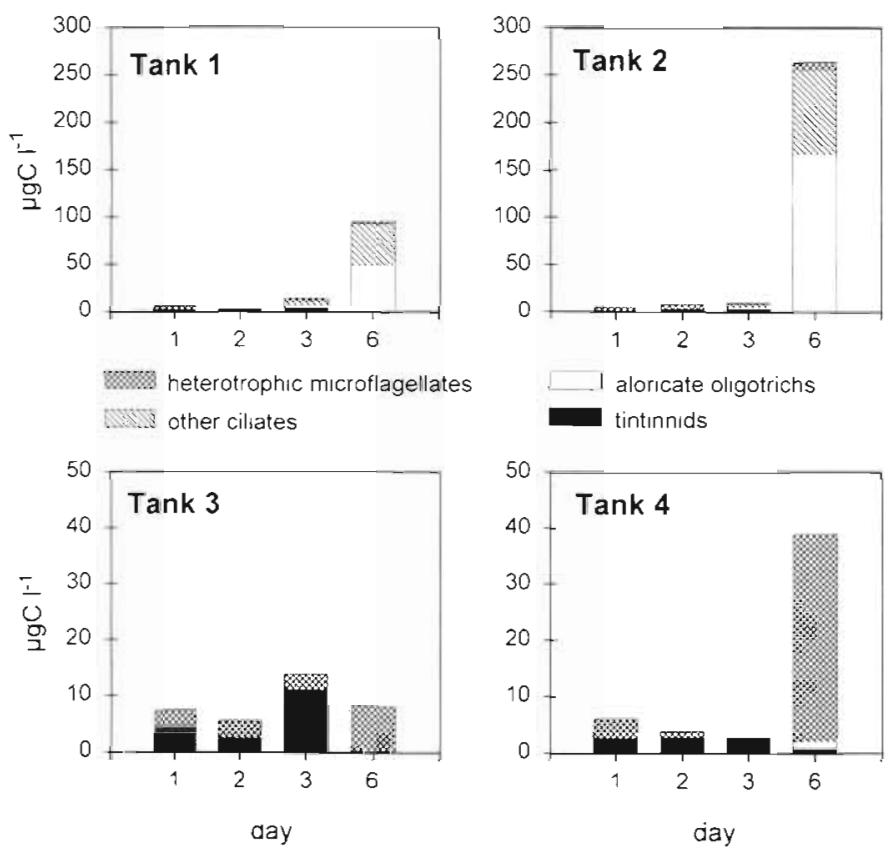

Fig. 4. Microprotozoan biomass and the succession of species groups during the experiment. Note the different scales in the upper and lower figures
Table 2. Numbers of individuals and biomasses ( $\mu \mathrm{g}$ wet $w \mathrm{t}^{-1}$ ) of the metazooplankton added in Tanks 3 and 4

\begin{tabular}{|c|c|c|c|}
\hline Main group & Species & Ind $1^{-1}$ & $\begin{array}{c}\text { Biomass } \\
\left(\mu g l^{-1}\right)\end{array}$ \\
\hline \multirow[t]{5}{*}{ Rotatoria } & Synchaeta baltica & 16 & 32 \\
\hline & Asplanchna priodonta & 2 & 40 \\
\hline & Keratella cochlearis & 2 & 0.15 \\
\hline & K. cruciformis & 2 & 0.15 \\
\hline & K. quadrata & 40 & 8 \\
\hline \multirow[t]{3}{*}{ Cladocera } & Bosmina coregoni maritima & 342 & 3352 \\
\hline & Daphnia cucullata & 2 & 40 \\
\hline & Pleopsis polyphemoides & 14 & 168 \\
\hline \multirow[t]{8}{*}{ Copepoda/Calanoida } & Acartia bifilosa adults & 58 & 4640 \\
\hline & Copepodites IV-V & 226 & 4520 \\
\hline & Copepodites 1-IIl & 106 & 1113 \\
\hline & Nauplii & 8 & 8 \\
\hline & Eurytemora sp. adults & 12 & 924 \\
\hline & Copepodites IV-V & 16 & 320 \\
\hline & Copepodites I-III & 2 & 21 \\
\hline & Nauplii & 0 & 0 \\
\hline Copepoda/Cyclopoida & Nauplii & 2 & 2 \\
\hline Cirripedia & Balanus improvisus nauplii & 6 & 11 \\
\hline \multicolumn{4}{|c|}{ Metazoan total biomass: $15.2 \mathrm{mg}$ wet wt $\mathrm{l}^{-1}$ or $915 \mu \mathrm{g} \mathrm{C}^{-1}$} \\
\hline
\end{tabular}

The microprotozoan community development in Tanks 3 and 4 , with the added metazoans, was quite different from that in Tanks 1 and 2 (Fig. 4). In Tank 3, with no added nutrients, microprotozoan biomass remained approximately at the same level during the whole period. In Tank 4, on the last day, a clear increase in biomass was observed. The common factor between these 2 tanks was that only Ebria tripartita seemed to survive metazooplankton grazing, and during the last $3 \mathrm{~d}$ in Tank 4, to reach a growth rate comparable to that of the oligotrich ciliates in Tank $2\left(\mu=1.13 \mathrm{~d}^{-1}\right)$.

\section{Metazoan plankton}

As practically all metazooplankton were removed by the $100 \mu \mathrm{m}$ sieve, the only metazoans present in the experiment were those added to Tanks 3 and 4 (we did not observe any metazoans except a couple of specimens of tiny Synchaeta spp. in the samples from Tanks 1 and 2). The method of catching the zooplankton to be added (200 $\mu \mathrm{m}$ plankton net) almost completely eliminated all other zooplankton but crustaceans. The result of this procedure can be examined in Tâtele 2, wherêt the nuimbers of difforcnt mota zoans (sampled from Tank 4) are shown. Only $7.8 \%$ of all individuals were rotifers; all the rest represented different crustacean taxa. Metazoans 
were sampled only once, in the beginning of the experiment, because we expected no dramatic changes in their numbers during the $6 \mathrm{~d}$ period. The biomass of the added metazoans was calculated at the starting point $\left(15.2 \mathrm{mg}\right.$ wet wt $\mathrm{l}^{-1}$, corresponding to $912 \mu \mathrm{g} \mathrm{C}$ $\mathrm{I}^{-1}$ ), using partially volume-based organic carbon estimates; for Acartia bifilosa and Bosmina c. maritima actual carbon measurements were used.

\section{Microprotozoan and copepod grazing experiments}

Microprotozoan grazing experiments were conducted on Days 1, 2, 3, and 6 from Tanks 1 and 2. The results of the uptake of different particle sizes were pooled in 5 size classes, according to the 5 dominant algal groups or species present in the tanks (Table 3).

The water volume cleared by the microprotozoans in the 5 particle size classes as a percentage of total water volume in the Tanks 1 and 2 is presented in Fig. 5. As there was practically no change in the microprotozoan communities during the first $3 \mathrm{~d}$, the clearance rate results for these days are averages. In both tanks, the high protozoan growth between Days 3 and 6 had a clear effect on the clearance rates. During Days 1 to 3 , the water volume cleared by microprotozoans varied in the 2 tanks between 5 and $12 \% \mathrm{~d}^{-1}$, whereas on Day 6 , the corresponding variation was between 25 and $559 \%$ (depending on the particle size class). The prevailing tintinnid community on Days 1 to $3 \mathrm{did}$ not have a distinct selectivity pattern between particles from 2.8 to $21 \mu \mathrm{m}$. On the other hand, on Day 6, when the community had undergone the drastic change towards the dominance of aloricate oligotrich ciliates, there was a clear pattern in grazing on the 5 particle size classes, so that the greatest percentage of water cleared was observed in the smallest size class. With growing particle size, the cleared water volume diminished steadily, being less than 100\% in the largest size class in both tanks.

The results of the crustacean feeding experiments are presented in Table 4 . In general, the copepods were not feeding very actively on the food items

Table 3. The main representatives of the dominant algae and heterotrophic flagellates in the size classes corresponding to those of the microprotozoan clearance percentages (Fig. 5)

\begin{tabular}{|cl|}
\hline Size class $(\mu \mathrm{m})$ & Dominant representative \\
\hline $2.8-5.6$ & Unidentified flagellates \\
$5.6-7.0$ & Pyramimonas sp. \\
$7.0-9.8$ & Cryptomonas spp. \\
$9.8-12.6$ & Katodinium rotundatum \\
$12.6-21.0$ & Eutreptiella sp. \\
\hline
\end{tabular}
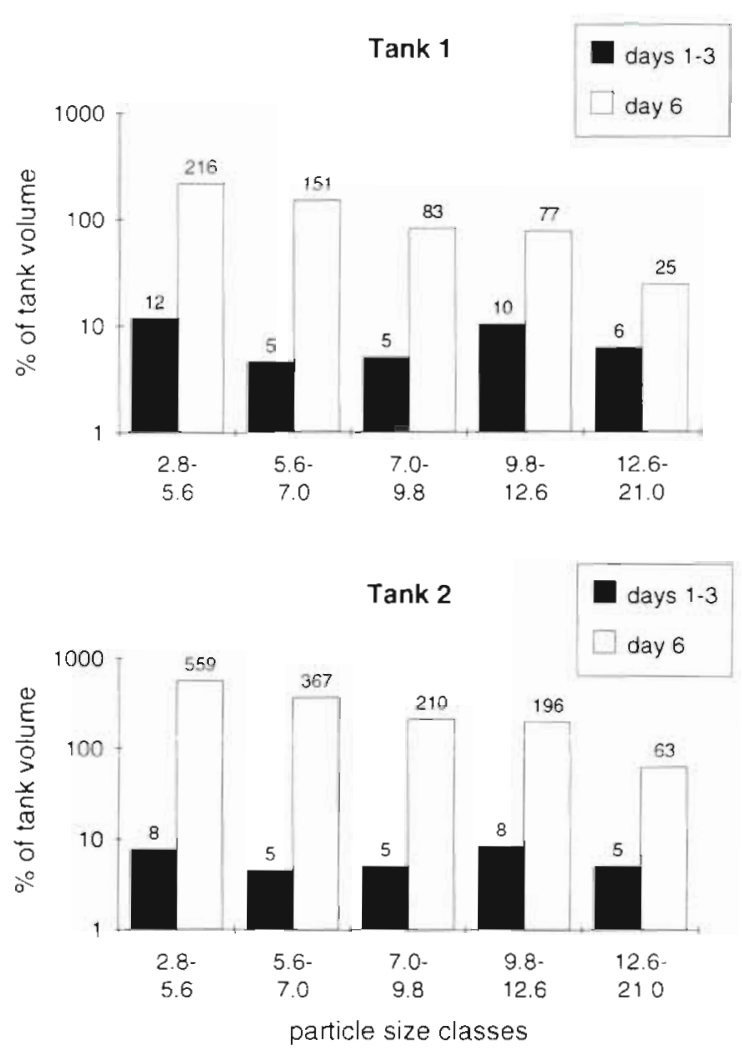

Fig. 5. Oligotrich ciliate clearance rates in Tanks 1 and 2 , expressed as the \% of water volume cleared of particles in the 5 size classes in $24 \mathrm{~h}$. The values from Days 1 to 3 are averages. Note the logarithmic scale on $y$-axis. If divided by 100 , the clearance percentages also express instant mortality rates (dimensionless) of the different prey size classes (see Sterner 1989)

offered (see 'Discussion'). The highest grazing rates were observed with Brachiomonas sp., the largest of the algae used. The relatively high grazing rates on the minute Synechococcus sp. may be connected with the tendency of the individual $<1 \mu \mathrm{m}$ cells of this picoplanktonic cyanobacteria to clump together in cultures, thus forming aggregates that can be retained on the calanoid sieving appendages. The calculated clearance rates for Acartia bifilosa (average clearance rate on Brachiomonas sp. $23 \mu \mathrm{l}$ ind ${ }^{-1} \mathrm{~h}^{-1}$, maximum rate $48 \mu$ ind $^{-1} \mathrm{~h}^{-1}$ ) from these experiments appeared to be quite low compared to those from other studies (e.g. Deason 1980), with a difference of at least an order of a magnitude. If we apply the average clearance rate to all copepodite (I to VI) stages of both $A$. bifilosa and Eurytemora sp., they were able to sweep $23.2 \%$ of the water volume clear of suitable food particles in $24 \mathrm{~h}$. To estimate the grazing impact of Bosmina c. maritima, we used the clearance rate of $66 \mu \mathrm{lnd} \mathrm{in}^{-1}$ $h^{-1}$, measured by DeMott (1986), with the result that the B. C. maritima population could go through $53.2 \%$ 
Table 4. Acartia bifilosa. The results of grazing experiments based on gut chl a content measurements with adult females (30 ind. $/ 500 \mathrm{ml}$ ). The chl a values are given for $24 \mathrm{~h}$, as $n g \mathrm{l}^{-1}$ or $\mathrm{ng}$ ind. ${ }^{-1}$ Tot. chl a ng eaten $\mathrm{l}^{-1}$. total amount of chlorophyll a eaten $\mathrm{l}^{-1}$ during the experiment; chl a ng ind. ${ }^{-1}$ : chl a eaten by 1 individual during the experiment: no.: number of experiments

\begin{tabular}{|lccccc|}
\hline Food & $\begin{array}{c}\text { Size } \\
(\mu \mathrm{m})\end{array}$ & $\begin{array}{c}\text { Tot. chl ang } \\
\text { eaten }^{-1}\end{array}$ & $\begin{array}{c}\text { Chl ang } \\
\text { ind }^{-1}\end{array}$ & No. \\
\hline Synechococcus sp. & $<1$ & $44.8 \pm 12.9$ & $1.6 \pm 0.5$ & 4 \\
Nannochloropsis sp. & $1-2$ & $11.8 \pm 0.8$ & $0.4 \pm 0.0$ & 2 \\
Pavlova sp. & ca 5 & $23.3 \pm 6.3$ & $0.8 \pm 0.2$ & 3 \\
Brachiomonas sp. & $>10$ & $81.5 \pm 48.0$ & $2.8 \pm 1.7$ & 5 \\
\hline
\end{tabular}

of the water volume daily. Altogether, according to these estimates, the crustacean populations were able to clear $76.4 \%$ of the water volume daily (the contribution of naupliar stages and rotifers being negligible).

\section{DISCUSSION}

\section{Regulation of primary production and phytoplankton standing stocks}

In our experiment, the Tanks 1 and 3 represented the oligotrophic state prevailing in the Gulf of Finland throughout most of the phytoplankton growth season, with the exception of early spring (the nutrients having accumulated since autumn) and the occasional summer upwellings, which bring inorganic nutrients to the surface layer (Niemi 1973). In the beginning of the experiment, the inorganic $N$ and $P$ concentrations were obviously high enough to maintain rather high primary production (Fig. 2). However, in the tanks with no nutrient additions, overall primary production levels dropped drastically during the first $24 \mathrm{~h}$ of the experiment. At least in Tank 1 this decrease could be interpreted as a sign of rapid inorganic nutrient depletion. In this tank, only protozoan grazers were present, and their numbers were low during the first $3 \mathrm{~d}$. Hence, the decline in primary production can not be attributed to extensive protozoan grazing, but seems to be the consequence of nutrient depletion. In Tank 3, with the high metazoan numbers, nutrient recycling should have been effective enough to provide phytoplankton with better growth conditions than in Tank 1, where the few protozoans probably had a negligible contribution to nutrient recycling during the first $3 \mathrm{~d}$. However, the quite similar primary productivity decline natterns in Tanks 1 and 3 support the conclusion that phytoplankton production in the $>1 \mu \mathrm{m}$ compartments was mainly limited by nutrient availability.
There were few changes in chl a concentrations during the $6 \mathrm{~d}$ of the experiment in the non-enriched tanks (Fig. 3). Total chl a remained at the initial level in both tanks, but in Tank 3 , the chl a in the $<1 \mu$ m fraction contributed significantly more to the total concentration than in Tank 1. This, again, may be interpreted as an indication of the minute algae being an unavailable food resource for metazoans. Day 6 , the highest chl a concentrations in tank 3 were recorded in the $1-10 \mu \mathrm{m}$ fraction, whereas in Tank 1, approximately $50 \%$ of chl a was found in this fraction, and practically all the rest in the $>10 \mu \mathrm{m}$ fraction. These results suggest that the considerable increase in microprotozoan populations in Tank 1 mainly utilized the 2 lower fractions as their food, while in the metazoan-dominated Tank 3 , the grazing pressure was highest towards the $>10 \mu \mathrm{m}$ phytoplankton.

In the nutrient-enriched tanks ( 2 and 4 ) the development of both primary production and chl a followed different patterns, and also deviated significantly of those in Tanks 1 and 3. In Tank 2, the nutrient additions clearly enhanced phytoplankton growth during the first $24 \mathrm{~h}$; this can be seen in the 4 -fold increase in total chl $a$ and also in some enhancement of primary production. The fast growth of phytoplankton in the 1-10 $\mathrm{\mu m}$ fraction apparently reflects both the low microprotozoan grazing pressure in this tank, and the ability of this phytoplankton fraction (mostly flagellated cells) to quickly take advantage of the nutrient enrichments. As towards the end of the experiment phytoplankton $>10 \mu \mathrm{m}$ became the dominant fraction, it may be taken as further proof of the fast-growing protozoan populations utilizing mainly $<10 \mu \mathrm{m}$ organisms as their food. In Tank 4 (Figs. $2 \& 3$ ), the changes in phytoplankton growth were more gradual, the most notable being the increase of the $1-10 \mu \mathrm{m}$ phytoplankton, in spite of the high numbers of crustaceans present. It seems evident that some organisms in this size class escaped metazoan grazing, and were able to gain from both nutrient enrichments and enhanced nutrient recycling by the metazoans. Phytoplankton $>10 \mu \mathrm{m}$ was not able to gain notably from the nutrient additions (as it did in Tank 2), probably due to its being the main food for the crustaceans.

\section{Bacterial production and picocyanobacteria}

Bacterial growth was greatly stimulated by inorganic nutrient additions (Tanks 2 and 4, Fig. 1A), and also somewhat enhanced by the presence of metazoonlankton even in the absence of extra nutrients. It appears that the responses of bacteria to the improved availability of inorganic nutrients were not dependent on whether the grazer community was dominated by 
microprotozoans or crustaceans, as the development of thymidine incorporation during the experiment was similar in Tanks 2 and 4 . On the other hand, bacteria may gain from the metazoan abundance even in nutrient-depleted situations by several ways. One of these is the benefit from the large metazoan population being able to recycle nutrients from the very beginning of the experiment (tank 3, Fig. 1A), in contrast to the recycling by microprotozoa (Tank 1), where nutrient recycling was probably effective only during the last couple of days.

The development of pico-sized cyanobacteria in all tanks bore some resemblance to that of bacterial production: highest final numbers were found in Tanks 2 and 4 , whereas the changes in Tank 1 were not very drastic (Fig. 1B). Again, in comparison with Tank 1, the cyanobacteria numbers in Tank 3 were somewhat higher from Day 3 on. The cyanobacteria found in the tanks were single, coccoid cells, which are considered to be too small for most metazooplankton to catch and ingest (Kleppel 1993), but may be utilized by microprotozoans (Kuosa 1990).

\section{Grazing by microprotozoans and metazoans, and their ecological interactions}

As the microprotozoans underwent a major community change during the last $3 \mathrm{~d}$ of the experiment in Tanks 1 and 2, both their total grazing efficiency and their structuring of the prey communities during Days 1 to 3 and Day 6 represent 2 levels in the top-down control exerted by them. The tintinnid community prevailing during the first $3 \mathrm{~d}$ could not control the growth of their prey due to their low community clearance rates (Fig. 5). Moreover, their feeding effort was divided rather evenly on the whole size range of ingested food particles (from 2.8 to $21.0 \mu \mathrm{m}$ ). Tintinnid clearance rates versus biomass ratios have been found to be comparable to that of aloricate oligotrichs (Kivi \& Setälä 1995). Thus, the low grazing impact of the tintinnid-dominated community simply reflects the low numbers of tintinnids present.

In contrast to the tintinnid community, the aloricates showed a clear pattern in their food preferences (Fig. 5). In both Tanks 1 and 2 their community structure was remarkably similar, in spite of the 2.5 -fold difference in total biomass, and this similarity was also reflected in their preferential food particle sizes. The aloricate strobilidids and strombidids preferred the smallest food items, and their grazing efficiencies were clearly lower on the largest particle size classes. However, even particles up to ca $20 \mu \mathrm{m}$ were also taken up by the aloricate ciliates.

Due to the low microprotozoan numbers in Tanks 3 and 4 , where practically no growth of aloricate oligo- trichs took place during the whole experiment, the grazing of the prevailing tintinnid community, during the first $3 \mathrm{~d}$ of the experiment, should be comparable with that in Tanks 1 and 2 . However, during the last $3 \mathrm{~d}_{1}$ some growth of the phagotrophic ebridian Ebria tripartita occurred, especially in Tank 4. E. tripartita is known to forage mainly on diatoms (K. Kivi pers, obs.) and because of its extracellular feeding mode (resembling the one described in Jacobson \& Anderson 1986), it does not take up starch particles; consequently, we have no observations of its feeding efficiency. However, its growth in the tanks with added metazooplankton suggests that there were some organisms present that E. tripartita could use as food, and also that it somehow (possibly due to unpalatability), unlike the aloricate ciliates, was able to escape metazoan predation

According to the results of the grazing experiments with Acartia bifilosa (Table 4), the copepods had a clear preference for $>10 \mu \mathrm{m}$ algae as food. The relatively high ingestion values of the pico-sized Synechococcus sp. can probably be explained by the tendency of this cyanobacteria to occur in clump-like formations (especially in cultures), although in the Baltic waters it does not form true colonies. Clumped together, the minute cyanobacteria can be retained on the sieving appendages of $A$. bifilosa, and thus contribute significantly to its diet in experimental conditions, in contrast to what happens in nature.

The grazing impact of crustaceans on their food organisms seems in the light of these results quite low compared to that of microprotozoans. In Tank 2, where the average clearance per day (on 2.8 to $21.0 \mu \mathrm{m}$ particles) was $279 \%$ on Day 6 , the corresponding carbon content of the grazers was only ca $270 \mu \mathrm{g} \mathrm{Cl}^{-1}$. The respective relationship for the crustaceans would be then $76.4 \%$ with ca $700 \mu \mathrm{g} \mathrm{Cl} \mathrm{Cl}^{-1}$, which suggests that aloricate oligotrich ciliates are quite effective grazers in relation to their biomass. However, there are many uncertainties in the Acartia bifilosa grazing measurements: for instance, the role of taste has been demonstrated to be an important factor in copepod food selection (Poulet \& Marsot 1978, Cowles et al, 1988. Kiørboe 1989). It is quite possible that some or all of the algae used in our experiments were not the most popular food for $A$. bifilosa, and thus, were ingested at considerably lower rates than more suitable food would have been. We have evidence (Kivi, Setälä \& Tanskanen unpubl.) that even at $8^{\circ} \mathrm{C}$, adult $A$. bifilosa females may have clearance rates up to ca $3 \mathrm{ml}$ ind.$^{-1} \mathrm{~h}^{-1}$, when aloricate ciliates in the 10 to $50 \mu \mathrm{m}$ size range are used as food organisms. If values like this were applied to our experiment, the picture on the role of crustaceans would change remarkably. In the presence of such discrepancy, we assume that a safe way to interpret the 
metazoan role in this experiment is to do it indirectly, by examining the effects the presence or absence of metazoans caused on other members of the food web.

\section{Conclusions}

The results of the experiment demonstrate in several ways that both bottom-up (resource availability) and top-down regulatory mechanisms appear to function simultaneously in the planktonic community. The growth enhancement by the $\mathrm{N}$ and $\mathrm{P}$ additions could be clearly observed in every organism group dependent on these resources (bacteria, picocyanobacteria and phytoplankton). However, attributing the changes during the experiment, for instance in bacterial production, only to the nutrient additions would overlook the complex interactions where inorganic nutrient recycling, exudation by phytoplankton and the increased organic substrate pool due to 'sloppy feeding' of zooplankton (Lampert 1978) should also be taken into account. An example of this kind of interaction of several factors producing enhanced resource availability can be seen in the comparison of bacterial production in Tanks 1 and 3, neither of which had any nutrient additions. The higher bacterial production level in Tank 3 is very probably the result of the crustacean zooplankton providing bacteria with resources by some or all of the 3 processes mentioned above. Thus, even if we restrict our view of the phenomena occurring at the lower trophic levels to the bottom-up type regulation, it would be useful to keep in mind that we are actually observing the outcome of multiple intertwined processes, working simultaneously within the planktonic food web.

One main conclusion to be made of our study is that planktonic protozoans, especially ciliates, are heavily controlled by metazoan grazing. Thus, the shaping effects of metazoan grazing can reach lower trophic levels by means of ciliate population control. In the trophic cascade, high metazoan grazing pressure will probably result in planktonic communities with a higher relative proportion of $<10 \mu \mathrm{m}$ unicellular organisms (as in Hansen et al. 1993). On the other hand, low metazoan grazing can lead to uncontrolled ciliate growth and to the consequent low biomass of smaller nanoplankton, but also to an increase in large phytoplankton biomass. Oviatt et al. (1989) found in an extended mesocosm experiment that high numbers of ciliates coincided with the increase of diatoms, while flagellates and monads (mainly $<10 \mu \mathrm{m}$ ) declined. This is in accordance with our short-term results, in which the dominance of ciliates also directed community grazing pressure to the $<10 \mu \mathrm{m}$ size class in our experiments.
It has been frequently argued that while filter-feeding cladocerans can ingest a wide range of differently sized particles, copepods show selectivity for larger food (e.g. Lampert \& Taylor 1984). In contrast to this, Roman et al. (1988) observed copepods consuming significant quantities of heterotrophic nanoflagellates. They also found, as in our study, that bacterial growth was stimulated by the presence of copepods. However, due to their experimental design, ciliates were excluded from the mesocosms, and the only food available for copepods consisted of small diatoms and flagellates. Lampert et al. (1986) observed an increase in plankton $<35 \mu \mathrm{m}$ in the absence of metazoan grazers, but they also do not discuss the role of ciliates in this process. In the presence of ciliates the copepods may switch their feeding mode to an 'ambush-and-attack' type foraging, concentrating on larger, motile prey which can trigger their attack mechanism by kinetic stimuli (Tiselius \& Jonsson 1992). In our experiment, the high proportion of the cladoceran Bosmina c. maritima may have caused the food spectrum of the metazoan community to extend lower than what would have happened with a copepod-dominated community (which is the prevailing type of metazoan communities in the northern Baltic during most of the annual productive period). As our results strongly suggest that the metazoans graze mainly on microplankton and larger nanoplankton, we conclude that their main role in shaping the Baltic plankton community is largely due to the regulation of these plankton components.

According to our results, the qualitative differences in ciliate and crustacean top-down control are reflected in the composition of their prey populations. For instance, the succession of the 3 different size fractions of chl a in Tanks 2 and 4, representing ciliate- and crustacean-dominated grazer communities, suggests that while the grazers may set the limits of the total phytoplankton biomass, the most profound differences may be found in the composition of phytoplankton, affected by the different prey preferences of the proto- and metazoans. Hence, it seems possible that planktonic communities with similar phytoplankton total biomasses but with different community structures of phytoplankton and their grazers could emerge under varying environmental conditions.

Acknowledgements. We thank the staff of Tvärminne Zoological Station, whose positive attitude helped in constructing and running the laboratory experiment. The comments of 3 anonymous reviewers heiped to improve the manuscript. Our special thanks to the group of undergraduate students who took interest in the experiment and helped to carry out many measurements. They know who they are. 


\section{LITERATURE CITED}

Børsheim KY, Bratbak G (1987) Cell volume to cell carbon conversion factors for bacterivorous Monas sp. enriched from seawater. Mar Ecol Prog Ser 36:171-175

Cowles TJ, Olson RJ, Chisholm SW (1988) Food selection by copepods: discrimination on the basis of food quality. Mar Biol 100:41-49

Deason EE (1980) Potential effect of phytoplankton colony breakage on the calculation of zooplankton filtering rates Mar Biol 57:279-286

DeMott WR (1986) The role of taste in food selection by freshwater zooplankton. Oecologia 69:334-340

Edler L (1979) Recommendations on methods for marine biological studies. Baltic Mar Biol Publ 5:1-3ن

Elser JJ, Elser MM, Mackay VA, Carpenter SR (1988) Zooplankton-mediated transitions between $\mathrm{N}$ - and P-limited algal growth. Limnol Oceanogr 33:1-14

Fuhrman JA, Azam F (1982) Thymidune incorporation as a measure of heterotrophic bacterioplankton production in marine surface waters: evaluation and field results. Mar Biol 66:109-120

Haas LW (1982) Improved epifluorescence microscopy for observing planktonic micro-organisms. Ann Inst Oceanogr 58:55-60

Hansen FC, Reckermann M, Klein Breteler WCM, Riegman R (1993) Phaeocystis blooming enhanced by copepod predation on protozoa: evidence from incubation experiments Mar Ecol Prog Ser 102:51-57

Jacobson DM, Anderson DM (1986) Thecate heterotrophic dinoflagellates: feeding behavior and mechanisms. J Phycol 22:249-258

Kivi K, Kaitala S, Kuosa $H$, Kuparinen J, Leskinen E, Lignell R, Marcussen B, Tamminen T (1993) Nutrient limitation and grazing control of the Baltic plankton community during annual succession. Limnol Oceanogr 38:893-905

Kivi K, Setälä O (1995) Simultaneous measurement of food particle selection and clearance rates of planktonic oligotrich ciliates (Ciliophora: Oligotrichina). Mar Ecol Prog Ser 119:125-137

Kiørboe T (1989) Phytoplankton growth rate and nitrogen content: implications for feeding and fecundity in a herbivorous copepod. Mar Ecol Prog Ser 55:229-234

Kiørboe T, Mohlenberg F, Nicolajsen F1 (1982) Ingestion rate and gut clearance in the planktonic copepod Centropages hamatus (Lilljeborg) in relation to food concentration and temperature. Ophelia 21:181-194

Kleppel GS (1993) On the diets of calanoid copepods. Mar Ecol Prog Ser 99:183-195

Kuosa H (1990) Protozoan grazing on pico-and nanophytoplankton in the northern Baltic Sea: drrect evidence from epifluorescence microscopy. Arch Hydrobiol 1.19:257-265

Lampert W (1978) Release of dissolved organic carbon by grazing zooplankton. Limnol Oceanogr 23:831-834

Lampert W, Fleckner W, Rai H, Taylor BE (1986) Phytoplankton control by grazing zooplankton: a study on the spring clear-water phase Limnol Oceanogr 31:478-490

This article was submitted to the editor
Lampert W, Taylor BE (1984) In situ grazing rates and particle selection by zooplankton: effects of vertical mugration Verh Int Verein Limnol 22:943-946

Latja R, Salonen K (1978) Carbon analysis for the determination of individual biomasses of planktonıc anımals. Verh Int Verein Limnol 20:2556-2560

Mackas D, Bohrer R (1976) Fluorescence analysis of zooplankton gut contents and an investigation of diel leeding patterns. J Exp Mar Biol Ecol 25:77-85

McQueen DJ, Post JR, Mills EL (1986) Trophic relationships in freshwater pelagic ecosystems. Can J Fish Aquat Sci 43: $1571-1581$

Mullin MM (1969) Production of zooplankton in the ocean the present status and problems. Oceanogr Mar Biol Ann Rev 7:273-314

Nielssen TG, Kiorboe T (1994) Regulation of zooplankton biomass and production in a temperate, coastal ecosystem. 2 Ciliates. Limnol Oceanogr 39:508-519

Niemi $\AA$ (1973) Ecology of phytoplankton in the Tvärminne area, SW coast of Finland. I. Dynamics of hydrography, nutrients, chlorophyll a and phytoplankton. Acta Bot Fenn 100:1-68

Niemi $M$, Kuparinen $\bar{J}$, Uusi-Rauva A, Korhonen K (1983) Preparation of ${ }^{14} \mathrm{C}$-labelled algal samples for liquid scintillation counting. Hydrobiologia 106:149-156

Oviatt C, Lane P, French F III, Donaghay P (1989) Phytoplankton species and abundance in response to eutrophication in coastal marine mesocosms. J Plankton Res 11: $1223-1224$

Poulet SA, Marsot P (1978) Chemosensory grazing by marine calanoid copepods (Arthropoda: Crustacea). Science 200 1403-1405

Rassoulzadegan F, Laval-Peuto M, Sheldon RW (1988) Partitioning of the food ration between pico-and nanoplankton. Hydrobiologia 159:75-88

Rhee GY, Gotham IJ (1980) Optimum N:P ratios and coexistence of planktonic algae. J Phycol 16:486-489

Roman MR, Ducklow HW, Fuhrman JA, Garside C, Glibert PM, Malone TC, McManus GB (1988) Production, consumption and nutrient cycling in a laboratory mesocosm. Mar Ecol Prog Ser 42:39-52

Sherr EB, Sherr BF (1988) Role of microbes in pelagic food webs: a revised concept. Limnol Oceanogr 33:1225-1227

Steele JH (1974) The structure of marine ecosystems. Harvard University Press, Cambridge, MA

Sterner RW (1989) The role of grazers in phytoplankton succession. In: Sommer U (ed) Plankton ecology. Springer, Berlin, p 107-170

Thingstad TF, Sakshaug E (1990) Control of phytoplankton growth in nutrent recycling ecosystems. Theory and terminology, Mar Ecol Prog Ser 63:261-272

Tiselius P, Jonsson PR (1992) Foraging behaviour of six calanoid copepods: observations and hydrodynamic analysis. Mar Ecol Prog Ser 66:23-33

Utermöhl H (1958) Zur Vervollkommnung der quantitativen Phytoplankton-methodik. Mitt Int Verein Theor Angew Limnol 9:1-38

Manuscript first received: August 31, 1995

Revised version accepted: Deckmber 22, 1995 